\title{
Social media for outbound leisure travel: a framework based on technology acceptance model (TAM)
}

\author{
Snigdha Singh and Pallavi Srivastava
}

\begin{abstract}
Purpose - The purpose of this paper is to explore the applicability of technology acceptance model (TAM) to explain the widespread acceptance and usage of social media (SM) for travel purposes by Indian outbound leisure travellers during their travel cycle.

Design/methodology/approach - The study has adopted a qualitative approach involving in-depth interviews of 30 respondents, who had taken at least one international vacation in the last 12 months. Content analysis was used to arrive at the conclusion.

Findings - Findings of the study are used to develop a conceptual model which upholds the validity of the TAM with perceived usefulness (PU) and perceived ease of use (PEU) as determinants of SM usage. The model has been extended to include perceived trust (PT) and social capital (SC) as important constructs to explain the travellers' use of SM. Disposition readiness (DR) of the user towards SM was found to have an effect on all the four constructs.

Originality/value - Theoretically, this study suggests a modification to the existing TAM, which shows a unidirectional effect of PU and PEU on attitude. This study suggests that the effect would be bi-directional where the attitude (DR) of the traveller towards SM usage will affect PU and PEU. Furthermore, this study extends the TAM to include PT and SC as important constructs to explain SM usage by travellers. This study provides valuable insights into the hospitality and tourism sector which might help in further segmentation of travellers leading to more customised service offerings.
\end{abstract}

Keywords Social media, Tourism, Technology acceptance model (TAM)

Paper type Research paper

\section{Introduction}

The Indian outbound travel industry has seen a steady growth, showing a compounded annual growth rate of 10.17 per cent by 2016 (India Tourism Statistics, 2017). Presently, India is ranked next to China in terms of fastest growing outbound market, with a prediction to grow 50m by 2020 as per the United Nations World Tourism Organization (Dasgupta, 2017). Indians were the third largest air travellers by nationality for the year 2017 as per data released by The International Air Transport Association (Sinha, 2018). A recent study suggests that the Indian outbound leisure travel segment has a promising potential as only 30 per cent of the total departures from India account for leisure travelling, as against a global average of 53 per cent (CAPA-Expedia, 2018). This upsurge in outbound leisure travel may be attributed to an increase in GDP over 7 per cent (Taborda, 2018), growing air connectivity due to low-cost carriers, rising disposable income of Indian middle class and growth of woman and senior travellers (Dasgupta, 2017). The peak Indian leisure travel season falls between April and June because of school Summer vacations and again from October to January to coincide with festivals and holiday season (CAPA-Expedia, 2018). The travellers tend to have a very short lead time for outbound travel and prefer word of mouth in planning of travel. Here, social media (SM) tends to inspire travel more than any other form of interaction.
Snigdha Singh is based at Amity Business School, Amity University Uttar Pradesh, Lucknow, India.

Pallavi Srivastava is based at Jaipuria Institute of Management, Lucknow, India.

Received 6 October 2018 Revised 16 January 2019 Accepted 6 March 2019

(C) Snigdha Singh and Pallavi Srivastava. Published in Journal of Tourism Futures. Published by Emerald Publishing Limited. This article is published under the Creative Commons Attribution (CC BY 4.0) licence. Anyone may reproduce, distribute, translate and create derivative works of this article (for both commercial and non-commercial purposes), subject to full attribution to the original publication and authors. The full terms of this licence may be seen at http://creativecommons. org/licences/by/4.0/legalcode 


\subsection{Social media usage in India}

SM usage in India has witnessed a massive surge in recent times. It is estimated that India has over 450m internet users in 2016, with close to $216.5 \mathrm{~m}$ active SM users. (Statista: The Statistics Portal, 2017). India has world's largest number of Facebook users which number over 195m. Twitter, the micro-blogging site with $23.2 \mathrm{~m}$ monthly active users, Pinterest, with $110 \mathrm{~m}$ active users and Instagram with $16 \mathrm{~m}$ users are other popular SM sites used (Jain, 2016). Presently, 28.4 per cent of the Indian population $(375 \mathrm{~m})$ is using internet, out of which 10.3 per cent are active on SM (136m) with a growth rate of 15 per cent from 2015 (Yral Report, 2016).

\subsection{Social media and travel}

Information technology and the internet have significantly influenced the way travel-related information is disseminated and consumed by travellers (Choe et al., 2017; Fotis et al., 2012; Buhalis and Law, 2008). The use of SM is no longer restricted to information search but is fast becoming an integral part of the overall travel process. People use it to share their views and experiences and to create user-generated content (UGC), which in turn affects the travel choices of other travellers. Travel to a new destination is usually associated with risk (Fuchs and Reichel, 2011; Roehl and Fesenmaier, 1992), which increases manyfolds in the case of outbound travel. Their decision making involves a higher degree of uncertainty which translates to a greater need of information, for which they turn to SM. "Word of Mouse" holds significant relevance for them.

\subsection{Purpose of the study}

Research has shown the growing impact of SM on the travel and tourism industry (Xiang and Gretzel, 2010; Litvin et al., 2008), making it important to study the reason for its wide-scale acceptance. The technology acceptance model (TAM) was primarily chosen because of its simplicity and universality. There have been researchers that have upheld the applicability of TAM as far as general usage of SM is concerned. They have extended and/or integrated TAM with other established models to include vital social and individual parameters of perceived trust and enjoyment (Rauniar et al., 2014; Leng et al., 2011; Shin and Kim, 2008). Al-Ghaith (2015) introduced the concept of perceived social capital (SC) in relation to TAM. SC plays a significant role as far as SM usage by leisure travellers is concerned. Limited work has been done to study the use of TAM for SM usage specifically for travel (Ayeh et al., 2013). The role of SC and perceived trust (PT) in conjunction with PU and PEU for leisure travellers has not been explored.

Furthermore, very little work has been done to determine SM acceptance with special emphasis on developing countries. Since the internet penetration in these countries is still way behind the developed nations, an estimated 40.1 per cent in the developing nations vs 81 per cent in developed nations for the year 2016 (Statista: The Statistics Portal, 2017), the social and individual parameters as far as internet usage is concerned will be remarkably different. To the best of the researchers' knowledge, no studies could be found where TAM has been studied in the context of SM for different stages of outbound leisure travel of India. This study attempts to fill this gap.

\section{Literature review}

Travel and tourism is an information-based and information-sensitive industry (Ráthonyi, 2013). The rich wealth of UGC can prove highly influential in directing tourists' choices. The impact of electronic word of mouth (eWOM) on travel industry has been well established. Researchers have corroborated that eWOM has a significant impact on the travellers' intention to visit a destination (Arsal et al., 2008; Jalilvand and Samiei, 2012; Jalilvand et al., 2012; Ladhari and Michaud, 2015), which reduces pre-purchase doubt and post-purchase dissonance (Litvin et al., 2008) and positively affects hotel bookings (Ye et al., 2011). It enjoys a higher level of credibility than other sources of information (Gretzel and Yoo, 2008). In an interesting study conducted on Chinese consumers it was established that the perceived credibility of eWOM influences the effect of the eWOM (Park et al., 2011). Users from different countries exhibit different eWOM generation behaviour. A study conducted across seven countries indicated that users of Twitter in the USA 
and UK generated higher volumes of eWOM as compared with their Indian counterparts (Hodeghatta and Sahney, 2016). Prospective travellers use this UGC to reduce the risk of travelling and to enhance their travel confidence (Xiang and Gretzel, 2010). According to Wang and Fesenmaier (2004b), travel online communities provide functional, social, psychological and hedonic benefits to its members. Functional benefits are about information gathering without the barriers of time and space, whereas social benefits pertain to communication among the members leading to relationship building, exchange of ideas and opinions, and getting involved. Psychological benefits are accrued in the form of belongingness and affiliation for the group, while hedonic benefits are related to fun, enjoyment and amusement (Chung and Buhalis, 2008; Wang and Fesenmaier, 2004a). The web is shifting from business-to-consumer marketing to peer-to-peer model (Miguens et al., 2008). Together with decreasing uncertainty, the consumers wish to obtain a confirmation from their peers that they have planned the best trip (Ráthonyi, 2013). An opinion or recommendation from an acquaintance or friend has a huge impact on the tourists' travel decision-making process; it may even alter the original plan of tourists (Ráthonyi, 2013).

Travel 2.0 is a term used in the tourism literature to denote the impact of SM on travel (Dwivedi et al., 2011) and has been a subject of interest for many researchers (e.g. Fotis et al., 2012; Miguens et al., 2008; Schmallegger and Carson, 2008; Wenger, 2008; Pan et al., 2007, etc.). Kasavana et al. (2010) has discussed the scope and implications of 41 social networking sites for hospitality industry. This widespread usage of SM by travellers signifies that there is a general acceptance of SM by them and it becomes imperative to investigate the reasons for this acceptance of SM for travel purposes. To understand this phenomenon better, we look towards the TAM.

\subsection{Theoretical underpinnings: technology acceptance model}

Davis (1989) explained the acceptance of new technology within an organisation with the TAM. He stated that the "perceived usefulness" (PU) and "perceived ease of use" (PEU) of any new technology being introduced lead to their acceptance by the workers. He defined PU as "the degree to which a person believes that using a particular system would enhance his or her job performance" (p. 320). PEU was defined as "the degree to which a person believes that using a particular system would be free of effort" (p. 320). Both PU and PEU affected the workers' intention of using technology, which in turn determine their usage of the same. The success of TAM lies in its simplicity and universality. TAM has since been successfully extended to study the usage of various technologies such as online shopping, online consumer behaviour, attitude towards computers, acceptance of mobile technology, etc.

Mahmood et al. (2001) conducted a meta-analysis of the constructs of information technology usage in organisations. Of the 57 empirical studies that he investigated, he found a significant relation between PEU and PU to the actual usage of technology.

Rauniar et al. (2014) used TAM to investigate the adoption of Facebook, a popular social networking site, among users. In addition to PEU, which was taken as an antecedent for PU, they revised the TAM model to include the influence of the user's critical mass, social networking site capability, perceived playfulness and trustworthiness on the intention to use SNS.

Ayeh et al. (2013) used the TAM to predict the intention to use consumer-generated media for travel planning. While their study upheld the validity of the conventional TAM and its factors of PU and PEU, they also introduced additional distinct factors - travellers' perceptions of similarity of interest, trustworthiness and enjoyment - that play a significant role in predicting the usage of consumer-generated media for travel planning.

Though TAM has found widespread acceptance, it has also faced criticism by a number of researchers (Fu et al., 2006; Legris et al., 2003; Venkatesh and Davis, 2000; Malhotra and Galletta, 1999) who felt that it does not account for the social influence. Fu et al. (2006) felt that TAM had limited usage in explaining technology adoption outside the workplace as it did not consider the influence of social parameters, which are intrinsic to the use of SM. Legris et al. (2003) concluded that though TAM was "a useful model, but has to be integrated into a broader one which would include variables related to both human and social change processes" (p. 191). 
One such model that includes social parameters is the theory of planned behaviour (TPB) (Ajzen, 1991). TPB states that behavioural intention (BI) leads to actual behaviour. BI in turn has three independent determinants: first, attitude that refers to positive or negative feeling towards the behaviour; second, subjective norm that is the perceived social pressure to perform or not perform the behaviour; and finally, perceived behavioural control that is the perceived difficulty towards performing that behaviour.

Fusilier and Durlabhij (2005) compared the two models TAM and TPB to explain the usage of internet among Indian university-going students and found that both basic models effectively predicted internet usage intentions. Several other empirical studies suggest that TAM, when integrated with TPB, is better able to explain technology usage where human and social factors play important role (Leng et al., 2011; Ndubisi, 2006).

\section{Methodology}

\subsection{Research design}

The methodology used is exploratory and interpretive in nature. A qualitative approach involving semi-structured face-to-face interviews was deemed suitable for the purpose. Qualitative research studies stem from the belief that the experiences of people are context bound because of which values and interests become the part of the research process (Gupta and Awasthy, 2015). Data were collected and an attempt was made to establish patterns to develop a conceptual model. This was in line with the Strauss and Corbin's (1998) views where they state that the researcher begins his study with a wide area and subsequently allows theory to emerge from the data.

\subsection{Participants}

The unit of analysis was an individual who had taken at least one international vacation in the last 12 months. Overall 30 participants with such background were the subject of the study. The sample size for this study was determined by using the criterion of "saturation" (Patten, 2007). Individuals were chosen from different socio-demographic profiles to obtain an adequate representation of Indian outbound leisure tourists. A detail of the respondents' profile is given in Table I. Furthermore, the respondents were assigned individual codes from $\mathrm{R} 1$ through $\mathrm{R} 30$ to enable discussion (Table II).

\subsection{Instrument}

An interview schedule was prepared which included a set of pre-determined open-ended questions (Appendix 1). Some of the questions used were adapted from previous studies of Fotis et al. (2011) and Cox et al. (2008). The list of SM used for the study was based on the classification given by Kaplan and Haenlein (2010) which was modified to suit the needs of the present study (Appendix 2). Of the six heads under which they classified SM, three, social networking sites, blogs and collaborative sites, were included as given by them. Content communities were further broken down into photo sharing and video sharing sites to facilitate respondents' comprehension. Consumer review sites were included under a separate head as there was enough literature to support their importance in travel-related studies (Molinillo et al., 2016; Ayeh et al., 2013; O'Connor, 2008). Since no studies could be found linking virtual social worlds and virtual game world to the subject of the study, they were omitted.

Some probes were pre-planned to elicit more focused responses. At times, unplanned and impromptu probes were also used which was consistent with the views of Morse (1994). Since data analysis was conducted simultaneously as data collection, the emerging findings resulted in some modifications to the initial instrument.

\subsection{Data collection}

The interviews were conducted over a two-month period, June-July 2017. Purposive sampling was adopted where personal links were used to identify suitable respondents who had taken an international vacation during the last one year, ensuring that there was adequate representation of different age groups, professions, income groups and gender. This was done to reach 
Table I Profile of respondents

Characteristic

Numbers

Gender

Female

Male

Age (years)

$<25$

00

26-40

41-55

56-70

$>70$

Relationship status

Married

Single

Other

Education

Graduate

Post-graduate

Doctorate

Monthly household income (in INR*, lacs**)

$<1$

$1-3$

3-5

$>5$

International travel pattern

Very frequent ( $>2$ trips a year)

Frequent (at least one trip a year)

Moderate (at least one trip every 2 years)

Infrequent ( $<2$ trips so far)

Internet usage/day (in hours)

$>8$

$5-8$

$1-4$

$<1$

Social media usage

Several times/day

At least once a day

Sometimes/week

Rarely

Never

Type of social media used

Social networking sites (e.g. Facebook)

Photo/video sharing sites (e.g. YouTube/Instagram)

Photo/video sharing sites (e.g. YouTube/Instagram)

Consumer review sites (e.g.TripAdvisor, Zomato)

Blogs (e.g. Travel Blogs, Food Blogs)

Question and answer sites (e.g. Quora, Yahoo! Answers)

Notes: ${ }^{*} 1$ USD $=69.21$ INR (as on 1 April 2019); ${ }^{\star} 1 \mathrm{Lac}=100$ thousand

the sample quickly and efficiently. A snowball sampling technique was then adopted to reach out to other respondents. The interviews were conducted mainly in English but at times the local language, Hindi, was used to put the participant at ease. Each interview roughly lasted 25-30 min. All individuals voluntarily agreed to participate in this study.

The respondents were subjected to face-to-face or telephonic interviews. The purpose of the interview was briefly explained to them. The interviews were recorded after obtaining permission from 
Table II Respondent codes

S. No. Respondent codes Gender Age Relationship Education $\quad \begin{array}{cc}\text { Income } & \text { Internet usage per day } \\ \text { (in INR*, lacs**) } & \text { (in hours) }\end{array}$

\begin{tabular}{|c|c|c|c|c|c|c|c|c|}
\hline 1 & $\mathrm{R} 1$ & Female & $56-70$ & Other & Post-graduate & $3-5$ & $1-4$ & Sometimes/week \\
\hline 2 & $\mathrm{R} 2$ & Male & $56-70$ & Married & Post-graduate & $>5$ & $1-4$ & Several times/day \\
\hline 3 & R3 & Male & $41-55$ & Married & Doctorate & $>5$ & $1-4$ & Several times/day \\
\hline 4 & R4 & Male & $56-70$ & Married & Post-graduate & $3-5$ & $>8$ & At least once a day \\
\hline 6 & R5 & Male & $41-55$ & Married & Post-graduate & $1-3$ & $5-8$ & Several times/day \\
\hline 7 & R6 & Male & $56-70$ & Married & Graduate & $3-5$ & $1-4$ & Sometimes/week \\
\hline 5 & $\mathrm{R} 7$ & Female & $56-70$ & Married & Post-graduate & $>5$ & $<1$ & Several times/day \\
\hline 8 & $\mathrm{R} 8$ & Male & $56-70$ & Married & Graduate & $>5$ & $5-8$ & Sometimes/week \\
\hline 9 & R9 & Male & $26-40$ & Single & Graduate & $>5$ & $>8$ & At least once a day \\
\hline 10 & R10 & Female & $41-55$ & Married & Post-graduate & $3-5$ & $1-4$ & Several times/day \\
\hline 11 & $\mathrm{R} 11$ & Male & $41-55$ & Married & Post-graduate & $3-5$ & $>8$ & Several times/day \\
\hline 12 & $\mathrm{R} 12$ & Male & $56-70$ & Married & Post-graduate & $>5$ & $>8$ & Several times/day \\
\hline 13 & $\mathrm{R} 13$ & Male & $26-40$ & Married & Post-graduate & $>5$ & $1-4$ & At least once a day \\
\hline 14 & $\mathrm{R} 14$ & Male & $41-55$ & Married & Post-graduate & $>5$ & $>8$ & At least once a day \\
\hline 15 & $\mathrm{R} 15$ & Female & $41-55$ & Married & Post-graduate & $3-5$ & $1-4$ & Several times/day \\
\hline 16 & R16 & Female & $26-40$ & Married & Post-graduate & $3-5$ & $>8$ & Several times/day \\
\hline 17 & $\mathrm{R} 17$ & Female & $41-55$ & Other & Doctorate & $1-3$ & $<1$ & Sometimes/week \\
\hline 18 & $\mathrm{R} 18$ & Female & $56-70$ & Married & Post-graduate & $>5$ & $<1$ & Several times/day \\
\hline 19 & R19 & Male & $41-55$ & Married & Post-graduate & $>5$ & $1-4$ & Several times/day \\
\hline 20 & $\mathrm{R} 20$ & Female & $41-55$ & Married & Post-graduate & $>5$ & $5-8$ & Several times/day \\
\hline 21 & $\mathrm{R} 21$ & Female & $41-55$ & Married & Post-graduate & $3-5$ & $1-4$ & Several times/day \\
\hline 22 & $\mathrm{R} 22$ & Female & $41-55$ & Married & Post-graduate & $3-5$ & $1-4$ & At least once a day \\
\hline 23 & $\mathrm{R} 23$ & Female & $41-55$ & Single & Doctorate & $>5$ & $>8$ & At least once a day \\
\hline 24 & $\mathrm{R} 24$ & Female & $56-70$ & Married & Post-graduate & $1-3$ & $1-4$ & Several times/day \\
\hline 25 & $\mathrm{R} 25$ & Female & $41-55$ & Married & Post-graduate & $1-3$ & $>8$ & Several times/day \\
\hline 26 & $\mathrm{R} 26$ & Male & $41-55$ & Married & Post-graduate & $3-5$ & $5-8$ & At least once a day \\
\hline 27 & $\mathrm{R} 27$ & Female & $26-40$ & Married & Post-graduate & $3-5$ & $<1$ & Sometimes/week \\
\hline 28 & $\mathrm{R} 28$ & Female & $26-40$ & Married & Post-graduate & $>5$ & $5-8$ & Several times/day \\
\hline 29 & $\mathrm{R} 29$ & Female & $41-55$ & Married & Post-graduate & $>5$ & $5-8$ & Several times/day \\
\hline 30 & $\mathrm{R} 30$ & Female & $26-40$ & Married & Post-graduate & $3-5$ & $1-4$ & Several times/day \\
\hline
\end{tabular}

the participant. While the participant was speaking, some notations were also made on the questionnaire. Effort was made to transcribe the interviews on the day they were conducted after listening to the recordings more than once, to ensure that no detail was overlooked.

\subsection{Analysis}

A content analysis approach was adopted to extract meanings from the transcripts. The transcripts of the interviews were read and re-read to ensure no nuance was missed. They were identified, analysed, coded and categorised into themes from a set of responses (Boyatzis, 1998). Since the sample size was relatively small and thus manageable to analyse, the responses were coded manually (Saldaña, 2009) along similar lines to enable comparison and analysis. Analysis leads to trends emerging from the data. An attempt was made to establish patterns to develop a conceptual model.

\section{Development of conceptual model}

Findings show that the intention to use SM for travel-related purposes is the result of four main constructs: PU, PEU, perceived trust (PT) and SC. These constructs affect different stages of the travel cycle to varying degrees. It is further observed that these constructs would affect SM use only if the user has the DR to engage with SM. The frequency of travel and frequency of usage of SM potentially act as moderating variables. Putting these facts together, a conceptual model has been developed (Figure 1).

The main constructs are briefly discussed as under. 


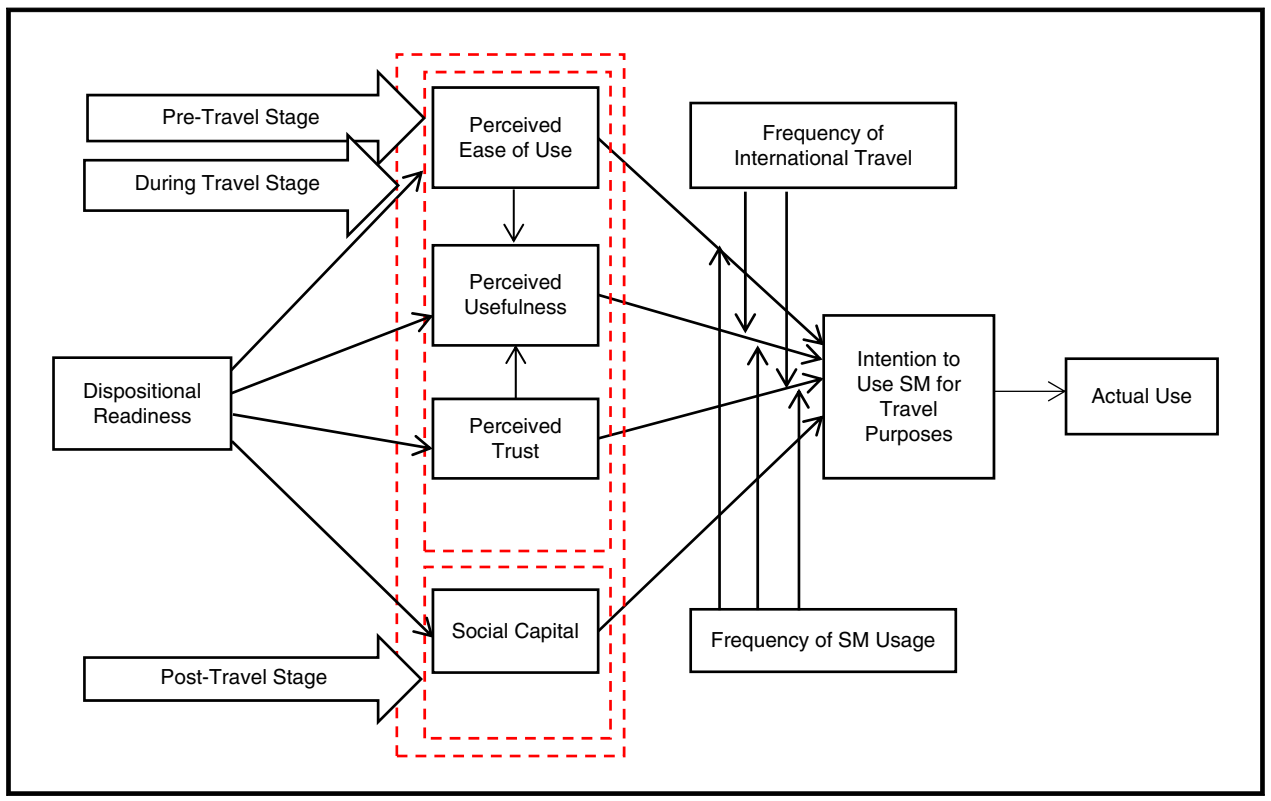

\subsection{Perceived usefulness}

PU conveys the extent to which the travellers believe that using SM will help them in their travel experience. The travellers seek to reduce the risk associated with travel and for that they consult all possible resources. They will choose to use SM only if they see more benefit in it vis-à-vis the traditional sources of information. To enable a better understanding of how this construct affects different stages of the travel cycle, we segregate the discussion into three stages - pre, during and post-travel.

4.1.1 Perceived usefulness and the travel cycle - pre-travel stage. Pre-travel stage is marked by finding motivation for travel, destination decision, information gathering, decision-making and planning process. It emerges from this study that SM is used extensively in the pre-travel stage. Though UGC was often not the immediate trigger for vacations, it was frequently used for destination decision where it was significantly supported by traditional WoM, tour operators, books and travel magazines. The maximum use of SM in the pre-travel stage was seen for information search post-destination decision. A total of 80 per cent of the respondents used SM to research the destination before actually leaving. "[...] had limited time for the holiday so did a lot of research (online) before leaving" (R20). They went through the results that the search engines (predominantly Google) brings up. "While researching the destination, something interesting may pop-up" (R12).

They used SM to find flights, accommodation and to finalise the itinerary. It saved them the time to physically collect information from the more traditional sources. They also used it to find out about the culture, customs, weather, etc., of the destination. SM helped them get an overview of the place before actually reaching there. "They (YouTube videos of the location) give me the actual feel" (R13). "If no SM [sic.], we would not have had such a rich experience" (R24).

A number of respondents mentioned using filters to customise their experience. This is a feature that is not as readily available with the traditional information sources. The travellers used filters to look for places or activities best suited for them. "Filters [...] by use of filters I can customize my trip (R22)". "I simply looked for places with good casinos [...]" (R8) (for deciding the travel destination). A family with young boys "looked for holiday spots which offered children centric activities and theme parks" (R11).

Respondents whose trip was planned by tour operators also used SM to "finalise which operator to choose" (R25) and to "guide the operator on how the best packages can be made" (R5), on 
what to include and what to leave out from the itinerary. SM thus adds to the convenience, saves time, helps in customising and gives information during the pre-travel stage of the travel cycle.

4.1.2 Perceived usefulness and the travel cycle - during-travel stage. During-travel stage is the period of travel starting from the departure to the point of arrival in the hometown and is related to needs that arise while travelling. Only 60 per cent respondents used SM during the travel, though the areas of use largely remain the same. Respondents used it for information if they wished to modify their itinerary. One respondent who was the part of a group tour "quickly referred to Trip Advisor for the closest mid-range shopping area when we had half a day to ourselves" (R25). They used it for checking restaurant reviews. "[...] he (co-traveller) was browsing on his phone and he discovered Botín, the oldest restaurant in the world, [...] called them and booked, all on the move" (R12). Most used SM for staying connected with friends and family back home. Some of them (33 per cent) used it for updating their profile pictures.

4.1.3 Perceived usefulness and the travel cycle-post-travel stage. Post-travel stage starts from the time of return to the hometown. In this stage, SM was mainly used to fulfil social needs which shall be discussed further in the paper.

\subsection{Perceived ease of use}

PEU refers to the ease with which the user can operate the SM sites. It determines whether or not the user has to make some extra effort to engage with a SM site. A site that is user friendly and easy to operate ensures an overall positive SM experience for the user. If the users perceive it complicated and difficult to use, they would avoid using it. Based on the PEU of SM, the users can very distinctly be divided into two groups - the first are the kinds who are comfortable with technology and adapt to new features on existing sites very comfortably. They do not have to actively learn to use the sites. For the second kind, using SM takes effort. They get intimidated by the many features that the sites have to offer. If they perceive the SM site to be complicated and its features prohibitive, they would avoid using it altogether.

4.2.1 Perceived ease of use and the travel cycle. PEU affects all the three stages of the travel cycle. The respondents, who perceived SM easy to use, used it for pre-, during and post-stages of the travel. They had a moderate to high SM usage per day and were comfortable operating different types of SM, linking one SM type with the other. They used it instinctively during their travel experience. For those who did not have a high level of PEU displayed low SM usage. They did have SM presence, primarily on Facebook, but were not very comfortable using it. They displayed limited use of SM for the travel cycle. "Why would I tax myself with technology when I can simply ask" (R2). However, post-travel phase, even respondents who did not have a high level of PEU, but were positively disposed towards using SM, used it to share pictures of the trip.

\subsection{Perceived trust (PT)}

Perceived trust (PT) is the belief that the information that the user finds on SM with respect to his travel needs is objective, reliable and relevant. SM consists of user-generated comments and personal travel experiences. The extent to which the travellers rely on these posts to make their own travel decisions is the PT of the SM site. There are different types of SM, and each has a different perception of trustworthiness associated with it. Wikis are normally taken as the most trustworthy SM site with a number of respondents mistaking them to be the official sites of destinations. When questioned "Did you consult the official travel site?" the response often was "Yes we did refer to Wikipedia" (R4). Facebook posts are also considered reliable, though to a lesser degree, since they are posted by known "friends" while consumer review sites evoked a mixed response.

4.3.1 Perceived trust and the travel cycle. In the present study, PT played an important role in the pre-travel phase primarily for destination decision and information search. In total 48 per cent of travellers relied more on SM postings than posts on official tourist websites, with more than 40 per cent trusting the information to make changes in their schedule. They considered the information found on SM unbiased and objective. They also found more real time information on it 
vis-à-vis the official sites. The official sites are "often slow to respond to immediate changes in the travel circumstances like closure of the place for a couple of days for maintenance or changes in the visiting hours" (R26). Some official hotel sites would also not mention the deals that are possible - "can get an additional bed in the hotel room instead of booking a separate room for kids" (R11).

During the travel, PT was exhibited in the use of SM to check for restaurant reviews and for studying reviews of things to do at the destination. "Consumer review sites give more usable information like 'this place is not safe after 5:30'. That's something official sites will NEVER tell” (R26).

PT did not play an important role in the usage of SM in the post-travel stage.

\subsection{Social capital}

SC is defined as the propensity of individuals to associate together on a regular basis, to trust one another and to engage in community affairs (Hall, 1999). Individuals with a large social circle who tend to connect and interact more with people are said to have a higher SC. The concept may be extended to the internet world and translate to the number of online contact and interactions. The number of likes on a Facebook post, the number of followers on Instagram or Twitter, the number of responses on a blog is a reflection of the online SC of an individual. Generating SC is one of the main motivations of using social networking sites (Ellison et al., 2007).

4.4.1 Social capital and the travel cycle - pre- and during stage. There was a near absence of SC application in the pre-travel stage. In the during-travel stage, SC was exhibited by the use of SM to stay connected with friends or to share pictures on SNS.

4.4.2 Social capital and the travel cycle - post-travel stage. There were different reasons given for using SM post-travel and most of them can be attributed to SC. In all, 82 per cent of respondents used the SM post their trip to upload pictures, share travel experience or to post reviews of the destinations visited. Even respondents who did not use SM all through their trip (pre- and during travel) used it post their vacation. SC was seen to be manifested in the following forms.

4.4.2.1 Altruism. It includes posting travel pictures and experiences on Facebook or Instagram so that others can gain from their experiences:

"[...] to let my friends know that I have been there and they can get first-hand information from me",

(R25) "to share experiences, to motivate others to travel" (R5).

The same reason was given for posting reviews of places visited on consumer review sites, especially if something was not up to the expectation. "(I) post reviews only if the experience is very good or very bad - to warn others" (R10).

4.4.2.2 Sharing. In today's time people have large extended families, scattered all over the globe. They like to share their travel pictures online "just like I share photo albums with family" (R16):

"To share the excitement with and family and friends as it was a big achievement to get my elderly parents to travel". (R28)

4.4.2.3 Conforming. Posts of friends on SM seem to be one of the reasons of posting pictures online, to keep up with friends and family. Travellers upload pictures on Facebook and Instagram to conform to the existing social norms. "Everyone posts about their foreign trips, so I did too" (R5). At times a degree of peer pressure is also observed as a reason to share pictures. "To show that I too took an international vacation" (R11).

4.4.2.4 Bragging. This was one of the more difficult aspects to capture in the study as few would actually admit that it was one of the motivators for sharing pictures online - "I don't, but my friends definitely indulge in some bit of holiday bragging" (R13). Barring some respondents who confessed to bragging, "Of course! A picture in front of the Eiffel HAS to go on my FB!" (R22), most of them accepted that the likes and appreciation on the pictures do motivate them for future travel. 


\subsection{Dispositional readiness}

An important dimension that seems to affects the above constructs is the user's DR towards SM. DR may be explained as the user's willingness to engage with SM or his attitude towards it. There are a number of users who are not positively disposed towards SM usage. They consider it a "waste of time" (R17) and take it to be an idle person's entertainment "I have better things to do" (on being asked how often they use SM) (R7). They dislike the "constant exposure" (R19) that SM platforms provide and the breach of privacy that it results in. They look down upon users who are constantly engaged with SM. These users may perceive SM easy to use but will still avoid engaging in it as far as possible. For the same reasons, they will not consider it useful and will have limited trust on its content. They will also avoid posting pictures or sharing experiences online as they consider that it results in unwarranted attention from others. "We do not believe in these things" (R21) (on being asked whether she shared her vacation photos on SM).

In addition to the above-mentioned constructs, two more factors are seen to have a moderating effect on the intention to use SM for travel purposes - frequency of international travel and frequency of usage of SM.

\subsection{Frequency of international travel}

People who travel overseas frequently - whether for business or leisure - will be more at ease with international travel and for them travel decisions will be more routine, requiring less of time and effort for information search. Chances of them basing their decisions on online search will be higher than those who are going for the first time or travel infrequently. For the latter kind, it will be extensive problem solving and chances are that they will base their decisions on a more dependable source such as a tour operator or friends and relatives (Fodness and Murray, 1999). The frequency of international travel would thus affect the PU of SM as well as perceived trust.

\subsection{Frequency of social media usage}

Another factor that needs to be considered is the respondents' frequency of SM usage. The skill needed to obtain information online is often the result of learning by doing. A respondent who has more experience in using SM is more likely to be more skilled at searching for information online (Lehto et al., 2006). Hence, the frequency of usage of SM should directly affect the PEU and PU. It will also affect the perceived trust as when one becomes more familiar with a media, he/she will consider it more trustworthy than those who do not use SM that often.

\section{Discussion}

This paper has made an attempt to understand the acceptance and usage of SM for Indian outbound leisure travellers. This study establishes that SM is extensively used at all the stages of the travel cycle though to different degrees and for different reasons. This study upholds TAM to conclude that PU and PEU successfully predict the acceptance and usage of SM for outbound leisure travel. In addition to PU and PEU, perceived trust is an important predictor of SM usage by outbound travellers. This is consistent with previous studies that have shown that trust is an important antecedent of usage intention, especially where buyer-seller transactions are concerned like e-commerce and online shopping (Gefen et al., 2003a, b; Ha and Stoel, 2009; Pavlou, 2003) or when risk perception is high like payment of online taxes (Wu and Chen, 2005) and internet banking adoption (Kesharwani and Singh Bisht, 2012). The model is further extended to include SC as the other important dimension affecting SM usage for travel. Choi and Chung (2013) suggested that SC was an important extension to TAM for the acceptance and usage of social networking sites. The study also suggests that the DR of the user towards SM usage will affect all the four constructs. If the users are not positively disposed towards SM, they will not use it even if they are equipped with the relevant skills to do so.

The findings also suggest that the frequency of international travel and frequency of usage of SM have a potential moderating effect on the usage of SM for travel. When acting together, they will increase the dependency on SM for travel. If either of the two is not present, the traveller will turn to more traditional sources for his travel needs. 


\section{Implications}

This study makes a significant contribution in the body of knowledge pertaining to the tourism industry. This paper has both theoretical as well as managerial implications.

\subsection{Theoretical implications}

This study has two important theoretical implications. A revised TAM is proposed for explaining the use of SM for travel. The findings suggest that the constructs PU and PEU are supported by PT and SC as important additional constructs that would better explain the use of SM for travel.

Furthermore, an important modification to the TAM is suggested. The existing model suggests that PU and PEU have a unidirectional effect on the attitude towards technology. The findings suggest that the attitude (DR) towards technology (SM in this case) will also affect PEU and PU. DR would also affect PT and SC in this case.

\subsection{Managerial implications}

Since DR is seen to impact all the four constructs and hence SM acceptance and usage, it is important to have the users positively inclined towards SM usage. In recent times, there has been a growing concern against the use, over use and misuse of SM. SM platforms should take cognisance of this. Enabling the user to better control screen time, to secure user privacy, building in checks to control "fake news" or fake content are some methods that can be adopted by them. The recent launch of digital well-being controls by Apple is a step in the right direction (Bloomberg, 2018).

A number of respondents remarked on the official tourism sites not being user friendly, engaging and interactive. The official tourist sites thus need to marry the authenticity of their sites with the responsiveness, attractiveness and interactivity of SM. High level of responsiveness can be achieved by incorporating chat bots, the multi-lingual $24 / 7$ chat agents, that enable organisations to provide real time solutions to customer queries worldwide. These bots can learn natural language and simulate human conversation accurately (Delamater, 2018). Community forums, chat rooms, links to Facebook pages, twitter handles, blogs and trending news related to that destination add to the attractiveness of the sites. According to Dwivedi et al. (2011), SM icons should be strategically placed on the first page of the website in the form of original icons. This would enhance the probability of their use by the travel information seekers.

The use of SM analytics and mining of such data may result in valuable insights for the hospitality and tourism sector (Kozinets, 2002). This might help in further segmentation of consumers leading to more customised service offerings. Since most of the respondents stated that they googled their requirements and then went over the results, it is imperative that these sites work towards a high search engine optimisation.

It was seen that most travellers use SM for accommodation- and itinerary-related decisions, hence it is important that all tourist properties and other tourist organisations optimally use SM as a medium for advertising and promotion. Digital marketing tools could be used to target the advertisements of tourist-related organisations to very specific demographics on SM. As there was a high usage of SM to share pictures and experiences of the vacation, tourism destinations would benefit from providing opportunities for photography like creating or marking out selfie spots.

Travel service providers would do well to harness Web 4.0 technologies to provide travellers with new experiences like augmented realities and enhanced realism. The travellers would be prompted to share these experiences online, generating invaluable eWOM. It has been suggested that consumers are more likely to share their travel experiences online if they are made to feel unique (Ek Styvén and Foster, 2018). Web 4.0 technologies can play a pivotal role in providing travellers with services that are personalised to meet their unique needs and preferences. In fact, Travel 4.0 ensures that consumers enjoy experiences that are specially moulded to their liking (Buhalis and Amaranggana, 2015).

Since tourism is an experiential product, travel sites should adopt augmented reality marketing to enhance reality and provide the consumers an experience that is much more than physical reality (Dadwal and Hassan, 2015). They should offer sensory tourism information using narratives, 
virtual tours showcasing the rich travel experiences and reflect multisensory, fantasy and emotional cues. This creates a destination image which could be enhanced through photographic material (Govers and Go, 2004; Gretzel and Fesenmaier, 2003).

\section{Limitations and directions for future research}

This study favours qualitative over quantitative approach, hence limits the generalisability of results. The subsequent phase of this study would include an empirical testing and validation of the proposed conceptual model. Although the study does give a perspective on the topic of the research, because of limited sample size, it cannot be said that it is applicable to entire population of Indian outbound leisure travellers. Therefore, further research could include more participants not only from India but also from other countries to get a different perspective. The study focussed only on UGC and did not consider paid advertisements on SM sites. It would be interesting to study how paid advertisements affect the travellers' SM usage. The usage of SM during outbound leisure travel can be compared with its usage during domestic travel and travelling for business and meeting VFRs, etc. This would give an interesting insight into the bragging behaviour of travellers whether it exists only during outbound leisure travels or is same for any kind of travel. Also, it would be interesting to identify the antecedents of DR towards SM. Sentiment analysis can be used to study the travellers' feedback on blogs, micro-blogging sites like twitter, consumer review sites, etc. Future researchers could also look into the effects of Web 4.0 technologies on travel-related SM consumption.

\section{References}

Ajzen, I. (1991), "The theory of planned behavior", Organizational Behavior and Human Decision Processes, Vol. 50 No. 2, pp. 179-211.

Al-Ghaith, W. (2015), "Applying the technology acceptance model to understand social networking sites (SNS) usage: impact of perceived social capital", International Journal of Computer Science and Information Technology, Vol. 7 No. 4, pp. 105-17.

Arsal, I., Backman, S. and Baldwin, E. (2008), "Influence of an online travel community on travel decisions", in O'Connor, P., Höpken, W. and Gretzel, U. (Eds), Information and Communication Technologies in Tourism 2008, Springer Verlag, Vienna, pp. 82-93.

Ayeh, J.K., Au, N. and Law, R. (2013), "Predicting the intention to use consumer-generated media for travel planning", Tourism Management, Vol. 35 No. 1, pp. 132-43.

Bloomberg (2018), “Apple's new software will help you use your phone less often”, Time, 1 June, available at: http://time.com/5298442/apple-software-iphone-addiction/ (accessed 12 June 2018).

Boyatzis, R.E. (1998), Transforming Qualitative Information: Thematic Analysis and Code Development, Sage Publications, Thousand Oaks, CA, London and New Delhi.

Buhalis, D. and Amaranggana, A. (2015), "Smart tourism destinations enhancing tourism experience through personalisation of services", in Tussyadiah, I. and Inversini, A. (Eds), ENTER 2015 Proceedings, Lugano, Springer-Verlag, Wien, pp. 377-90.

Buhalis, D. and Law, R. (2008), "Progress in information technology and tourism management: 20 years on and 10 years after the internet - the state of eTourism research", Tourism Management, Vol. 29 No. 4, pp. 609-23.

CAPA-Expedia (2018), "The inflection point for India outbound travel", CAPA, available at: goo.gl/6DXMKT (accessed 8 July 2018).

Choe, Y., Kim, J. and Fesenmaier, D.R. (2017), "Use of social media across the trip experience: an application of latent transition analysis", Journal of Travel \& Tourism Marketing, Vol. 34 No. 4, pp. 431-43.

Choi, G. and Chung, H. (2013), "Applying the technology acceptance model to social networking sites (SNS): impact of subjective norm and social capital on the acceptance of SNS", International Journal of Human-Computer Interaction, Vol. 29 No. 10, pp. 619-28.

Chung, J.Y. and Buhalis, D. (2008), "Information needs in online social networks", Information Technology and Tourism, Vol. 10 No. 4, pp. 267-81. 
Cox, C., Burgess, S., Sellitto, C. and Buultjens, J. (2008), Consumer-Generated Web-based Tourism Marketing, Sustainable Tourism Cooperative Research Centre, Queensland.

Dadwal, S.S. and Hassan, A. (2015), "The augmented reality marketing: a merger of marketing and technology in tourism", in Ray, N. (Ed.), Emerging Innovative Marketing Strategies in the Tourism Industry, IGI Global, Hershey, PA, pp. 78-96.

Dasgupta, S. (2017), "Indian outbound tourists grow in number fastest growing outward-bound market after China", India Outbound, 26 May, available at: https://goo.gl/DffX6z (accessed 1 June 2018).

Davis, F.D. (1989), "Perceived usefulness, perceived ease of use, and user acceptance of information technology", MIS Quarterly, Vol. 13 No. 3, pp. 319-40.

Delamater, N. (2018), "A brief history of artificial intelligence and how it's revolutionizing customer service today", available at: https://bit.ly/2QLIMWN (accessed 15 January 2019).

Dwivedi, M., Yadav, A. and Venkatesh, U. (2011), "Use of social media by national tourism organizations: a preliminary analysis", Information Technology \& Tourism, Vol. 13 No. 2, pp. 93-103.

Ek Styvén, M. and Foster, T. (2018), "Who am I if you can't see me? The 'self' of young travellers as driver of eWOM in social media", Journal of Tourism Futures Vol. 4 No. 1, pp. 80-92.

Ellison, N.B., Steinfield, C. and Lampe, C. (2007), "The benefits of Facebook 'friends': social capital and college students' use of online social network sites”, Journal of Computer-mediated Communication, Vol. 12 No. 4, pp. 1143-68.

Fodness, D. and Murray, B. (1999), "A model of tourist information search behavior", Journal of Travel Research, Vol. 37 No. 3, pp. 220-30.

Fotis, J., Buhalis, D. and Rossides, N. (2011), "Social media impact on holiday travel planning: the case of the Russian and the FSU markets", International Journal of Online Marketing, Vol. 1 No. 4, pp. 1-19.

Fotis, J., Buhalis, D. and Rossides, N. (2012), "Social media use and impact during the holiday travel planning process", in Fuchs, M., Ricci, F. and Cantoni, L. (Eds), Information and Communication Technologies in Tourism 2012, Springer-Verlag, Vienna, pp. 13-24.

Fu, J.R., Farn, C.K. and Chao, W.P. (2006), "Acceptance of electronic tax filing: a study of taxpayer intentions", Information and Management, Vol. 43 No. 1, pp. 109-26.

Fuchs, G. and Reichel, A. (2011), "An exploratory inquiry into destination risk perceptions and risk reduction strategies of first time vs repeat visitors to a highly volatile destination", Tourism Management, Vol. 32 No. 2, pp. 266-76.

Fusilier, M. and Durlabhii, S. (2005), "An exploration of student internet use in India: the technology acceptance model and the theory of planned behaviour", Campus-Wide Information Systems, Vol. 22 No. 4, pp. 233-46.

Gefen, D., Karahanna, E. and Straub, D.W. (2003a), "Trust and TAM in online shopping: an integrated model", MIS Quarterly, Vol. 27 No. 1, pp. 51-90.

Gefen, D., Karahanna, E. and Straub, D.W. (2003b), "Inexperience and experience with online stores: the importance of TAM and trust", IEEE Transactions on Engineering Management, Vol. 50 No. 3, pp. 307-21.

Govers, R. and Go, F.M. (2004), "Projected destination image online: website content analysis of pictures and text", Information Technology and Tourism, Vol. 7 No. 2, pp. 73-89.

Gretzel, U. and Fesenmaier, D.R. (2003), "Experience-based internet marketing: an exploratory study of sensory experiences associated with pleasure travel to the Midwest United States", in Frew, A., Hitz, M. and O'Connor, P. (Eds), Information and Communication Technologies in Tourism 2003, Springer Verlag, Vienna, pp. 49-57.

Gretzel, U. and Yoo, K.H. (2008), "Use and impact of online travel reviews", in O'Connor, P., Hopken, W. and Gretzel, U. (Eds), Information and Communication Technologies in Tourism, Springer, New York, NY, pp. 35-46.

Gupta, R.K. and Awasthy, R. (Eds) (2015), Qualitative Research in Management: Methods and Experiences, Sage Publications India, New Delhi.

Ha, S. and Stoel, L. (2009), "Consumer e-shopping acceptance: antecedents in a technology acceptance model”, Journal of Business Research, Vol. 62 No. 5, pp. 565-71. 
Hall, P.A. (1999), "Social capital in Britain”, British Journal of Political Science, Vol. 29 No. 3, pp. 417-61.

Hodeghatta, U.R. and Sahney, S. (2016), "Understanding Twitter as an e-WOM", Journal of Systems and Information Technology, Vol. 18 No. 1, pp. 89-115.

India Tourism Statistics (2017), "Market research division, ministry of tourism", Government of India, pp. 91-2.

Jain, S. (2016), "101 latest social media facts and stats from India - 2016”, available at: www.soravjain.com/ social-media-facts-and-stats-india-2016 (accessed 24 July 2017).

Jalilvand, M.R. and Samiei, N. (2012), "The impact of electronic word of mouth on a tourism destination choice: testing the theory of planned behavior (TPB)", Internet Research: Electronic Networking Applications and Policy, Vol. 22 No. 5, pp. 591-612.

Jalilvand, M.R., Samiei, N., Dini, B. and Manzari, P.Y. (2012), "Examining the structural relationships of electronic word of mouth, destination image, tourist attitude toward destination and travel intention: an integrated approach", Journal of Destination Marketing \& Management, Vol. 1 Nos 1-2, pp. 134-43.

Kaplan, A.M. and Haenlein, M. (2010), "Users of the world, unite! The challenges and opportunities of social media”, Business Horizons, Vol. 53 No. 1, pp. 59-68.

Kasavana, M.L., Nusair, K. and Teodosic, K. (2010), "Online social networking: redefining the human web", Journal of Hospitality and Tourism Technology, Vol. 1 No. 1, pp. 68-82.

Kesharwani, A. and Singh Bisht, S. (2012), "The impact of trust and perceived risk on internet banking adoption in India: an extension of technology acceptance model", International Journal of Bank Marketing, Vol. 30 No. 4, pp. 303-22.

Kozinets, R.V. (2002), "The field behind the screen: using netnography for marketing research in online communities", Journal of Marketing Research, Vol. 39 No. 1, pp. 61-73.

Ladhari, R. and Michaud, M. (2015), "eWOM effects on hotel booking intentions, attitudes, trust, and website perceptions", International Journal of Hospitality Management, Vol. 46 No. 1, pp. 36-45.

Legris, P., Ingham, J. and Collerette, P. (2003), "Why do people use information technology? A critical review of the technology acceptance model", Information and Management, Vol. 40 No. 3, pp. 191-204.

Lehto, X.Y., Kim, D.Y. and Morrison, A.M. (2006), "The effect of prior destination experience on online information search behaviour”, Tourism and Hospitality Research, Vol. 6 No. 2, pp. 160-78.

Leng, G.S., Lada, S., Muhammad, M.Z., Ibrahim, A.A.H.A. and Amboala, T. (2011), "An exploration of social networking sites (SNS) adoption in Malaysia using technology acceptance model (TAM), theory of planned behavior (TPB) and intrinsic motivation", Journal of Internet Banking and Commerce, Vol. 16 No. 2, pp. 1-27.

Litvin, S.W., Goldsmith, R.E. and Pan, B. (2008), "Electronic word-of-mouth in hospitality and tourism management”, Tourism Management, Vol. 29 No. 3, pp. 458-68.

Mahmood, M.A., Hall, L. and Swanberg, D.L. (2001), "Factors affecting information technology usage: a meta-analysis of the empirical literature", Journal of Organizational Computing and Electronic Commerce, Vol. 11 No. 2, pp. 107-30.

Malhotra, Y. and Galletta, D.F. (1999), "Extending the technology acceptance model to account for social influence: theoretical bases and empirical validation", Proceedings of the 32nd Annual Hawaii International Conference on Systems Sciences.

Miguens, J., Baggio, R. and Costa, C. (2008), "Social media and tourism destinations: TripAdvisor case study", Advances in Tourism Research, Vol. 26 No. 28, pp. 26-8.

Molinillo, S., Ximénez-de-Sandoval, J.L., Fernández-Morales, A. and Coca-Stefaniak, A. (2016), "Hotel assessment through social media: the case of trip advisor", Tourism \& Management Studies, Vol. 12 No. 1. pp. 15-24.

Morse, J.M. (1994), "Designing funded qualitative research", in Denzin, N.K. and Lincoln, Y.S. (Eds), Handbook of Qualitative Research, Sage, Thousand Oaks, CA, pp. 220-35.

Ndubisi, N.O. (2006), "Factors of online learning adoption: a comparative juxtaposition of the theory of planned behaviour and the technology acceptance model", International Journal on ELearning, Vol. 5 No. 4, pp. 571-91. 
O'Connor, P. (2008), “User-generated content and travel: a case study of TripAdvisor.Com”, in O'Connor, P., Hopken, W. and Gretzel, U. (Eds), Information and Communication Technologies in tourism, Springer, Vienna and New York, NY, pp. 47-58.

Pan, B., MacLaurin, T. and Crotts, J.C. (2007), "Travel blogs and the implications for destination marketing", Journal of Travel Research, Vol. 46 No. 1, pp. 35-45.

Park, C., Wang, Y., Yao, Y. and Kang, Y.R. (2011), "Factors influencing eWOM effects: using experience, credibility, and susceptibility", International Journal of Social Science and Humanity, Vol. 1 No. 1, pp. 74-9.

Patten, M.L. (2007), Understanding Research Methods: An Overview of the Essentials, Pyrczak Publishing, Glendale, CA.

Pavlou, P.A. (2003), "Consumer acceptance of electronic commerce: integrating trust and risk with the technology acceptance model", International Journal of Electronic Commerce, Vol. 7 No. 3, pp. 101-34.

Ráthonyi, G. (2013), "Influence of social media on tourism - especially among students of the University of Debrecen", AgEcon Search, Vol. 7 No. 1, pp. 105-12.

Rauniar, R., Rawski, G., Yang, J. and Johnson, B. (2014), "Technology acceptance model (TAM) and social media usage: an empirical study on Facebook”, Journal of Enterprise Information Management, Vol. 27 No. 1, pp. 6-30.

Roehl, W.S. and Fesenmaier, D.R. (1992), "Risk perception and pleasure travel: an exploratory analysis", Journal of Travel Research, Vol. 30 No. 4, pp. 17-26.

Saldaña, J. (2009), An Introduction to Codes and Coding. The Coding Manual for Qualitative Researchers, Sage, Thousand Oaks, CA, pp. 1-31.

Schmallegger, D. and Carson, D. (2008), "Blogs in tourism: changing approaches to information exchange", Journal of Vacation Marketing, Vol. 14 No. 2, pp. 99-110.

Shin, D.H. and Kim, W.Y. (2008), "Applying the technology acceptance model and flow theory to cyworld user behavior: implication of the web 2. 0 user acceptance", Cyber Psychology and Behavior, Vol. 11 No. 3 , pp. 378-82.

Sinha, S. (2018), "Among fliers, Indians were the 3rd largest nationality in 2017", The Times of India, 8 September, p. 5.

Statista: The Statistics Portal (2017), "Internet usage in India - statistics and facts", available at: www.statista. com/statistics/255146/number-of-internet-users-in-india/ (accessed 23 June 2017).

Strauss, A. and Corbin, J. (1998), Basics of Qualitative Research Techniques, Sage Publications, Thousand Oaks, CA.

Taborda, J. (2018), "India GDP grows less than expected in Q4", available at: https://tradingeconomics.com/ india/gdp-growth-annual (accessed 27 August 2018).

Venkatesh, V. and Davis, F.D. (2000), "A theoretical extension of the technology acceptance model: four longitudinal field studies", Management Science, Vol. 46 No. 2, pp. 186-204.

Wang, Y. and Fesenmaier, D.R. (2004a), "Modeling participation in an online travel community", Journal of Travel Research, Vol. 42 No. 3, pp. 261-70.

Wang, Y. and Fesenmaier, D.R. (2004b), “Towards understanding members' general participation in and active contribution to an online travel community", Tourism Management, Vol. 25 No. 6, pp. 709-22.

Wenger, A. (2008), "Analysis of travel bloggers' characteristics and their communication about Austria as a tourism destination", Journal of Vacation Marketing, Vol. 14 No. 2, pp. 169-76.

Wu, L. and Chen, J.L. (2005), "An extension of trust and TAM model with TPB in the initial adoption of on-line tax: an empirical study", International Journal of Human-Computer Studies, Vol. 62 No. 6, pp. 784-808.

Xiang, Z. and Gretzel, U. (2010), "Role of social media in online travel information search", Tourism Management, Vol. 31 No. 2, pp. 179-88.

Ye, Q., Law, R., Gu, B. and Chen, W. (2011), "The influence of user-generated content on traveler behavior: an empirical investigation on the effects of e-word-of-mouth to hotel online bookings", Computers in Human Behavior, Vol. 27 No. 2, pp. 634-9.

Yral Report (2016), "Active social media users in India grow by 15\% from 2015 to become 136 million", available at: www.exchange4media.com/digital/active-social-media-users-in-india-grow-by-15-from-2015to-become-136-million-yral-report-2016_67225.html (accessed 24 July 2017). 


\section{Further reading}

Future Foundation (2015), "Future Travelers Tribe 2030: understanding tomorrow's traveller", Amadeus, Future Foundation, London.

Grover, B. (2017), “Top 5 reasons why people ‘Check-In' on Facebook”, blog Make My Trip, available at: www.makemytrip.com/blog/top-5-reasons-people-check-facebook (accessed 5 July 2017).

Hennig-Thurau, T., Gwinner, K.P., Walsh, G. and Gremler, D.D. (2004), "Electronic word-of-mouth via consumer-opinion platforms: what motivates consumers to articulate themselves on the Internet?", Journal of Interactive Marketing, Vol. 18 No. 1, pp. 38-52.

Kerr, G.M., Lewis, C. and Burgess, L. (2012), "Bragging rights and destination marketing: a tourism bragging rights model", Journal of Hospitality and Tourism Management, Vol. 19 No. 1, pp. 1-8.

Pavlou, P. (2001), "Integrating trust in electronic commerce with technology acceptance model: model development \& validation", AMCIS 2001 Proceedings, p. 159.

Xiang, Z. and Fesenmaier, D.R. (2014), "Information technology and consumer behavior in travel and tourism: insights from travel planning using the internet", Journal of Retailing and Consumer Services, Vol. 22 No. 1, pp. 244-9.

Yoo, K.H. and Gretzel, U. (2008), "What motivates consumers to write online travel reviews?", Information Technology and Tourism, Vol. 10 No. 4, pp. 283-95.

Yoo, K.H. and Gretzel, U. (2010), "Antecedents and impacts of trust in travel-related consumer-generated media", Information Technology and Tourism, Vol. 12 No. 2, pp. 139-52. 
Appendix 1. Interview schedule

\section{About You}

1. Name

2. Gender

3. Age: $<25 ; 26-40 ; 41-55 ; 56-70 ; 71<$

4. Relationship Status - Married Single

5. Children (Nos.)

6. Occupation

7. Highest Level of Education Completed:
a. Intermediate
b. Graduate
c. Post Graduate
d. Doctorate
e. Any Other

8. Monthly Family Income
a. less than Rs. 1L
b. Rs. $1 \mathrm{~L}-$ Rs. $3 \mathrm{~L}$
c. Rs. $3 \mathrm{~L}-$ Rs. $5 \mathrm{~L}$
d. More than Rs.5 L

9. City of Residence

\section{About Your Internet Usage}

10. On an average how many hours per day do you spend on internet and what do you primarily use it for?

\section{About Your Social Media Usage}

\section{(Refer list of Social Media - Appendix - B)}

11. How often do you visit any of these Social Media Sites?

12. What do you most like (or dislike) about Social Media?

\section{About your frequency of International travel}

13. How often do you take international trips
a. 2 or more trips in a year
b. At least 1 trip every year
c. At least 1 trip every 2 years
d. Less than 2 trips so far

\section{About your Holiday Trip}

\section{Let us talk about your last international vacation}
a. When was the trip taken?
b. Where
c. Duration
d. How many people
e. Nature of group 


\section{Before the Trip}

15. What was the trigger for taking your last vacation?

16. Where did you turn to for travel destination options?

(In case of unaided internet mention, probe for social media usage. In case social media not mentioned, ask specifically)

17. Was your destination choice at all influenced by the information you found on social media websites?

18. Once the travel destination was finalized, where did you turn to for gathering information for your trip?

(In case of unaided internet mention, probe for social media usage. In case social media not mentioned, ask specifically)

19. Did you use social media at all for travel planning? If yes, what did you primarily use it for? (If no, please proceed to question number 23)

\section{Trustworthiness of User Generated content}

20. Did you consult the official tourism websites of the country/ hotel/ theme park while planning your vacation? Did they help you - how?

21. Did you consult Consumer Review Sites while planning your vacation?

22. Between consumer reviews and official tourism sites which would you say are more helpful? Why?

23. If 'No' then where did you get the relevant information from?

\section{During the trip}

24. During your holiday did you use Social Media at all? Yes / No

25. If No - Was wi-fi accessibility an issue? If not an issue then why did you not use Social Media?

26. If yes, what did you use it for?

27. During your holiday did you make any changes to your original plans because of other travellers' opinions or photos that you found in social media websites?

28. What was the most influential source to decide on what to do? (Specific Attractions and Leisure activities)

\section{After the trip}

29. After the trip did you use Social Media at all?

\section{No / Yes}

30. If yes - what did you use it for and why?

31. If no then why not?

\section{Perceived Usefulness}

32. Overall, do you consider that social media helped you at all in planning your holidays, before, during or after? Let's discuss the top 3 reasons how you feel they helped you

33. Any other information that you would wish to share 
Appendix 2. List of social media ${ }^{a}$

1. Social networking sites
a. Facebook
b. Twitter
c. LinkedIn
d. Google +
e. Tumblr

\section{Video sharing sites}
a. YouTube
b. DailyMotion
c. Y!Videos

\section{Photo sharing sites}
a. Flickr
b. Instagram
c. Pinterest

4. Blogs

\section{Consumer Review Sites}
a. Trip Advisor
b. Bookings.com
c. Expedia.com

\section{Collaborative websites}
a. Wikipedia
b. Wikitravel

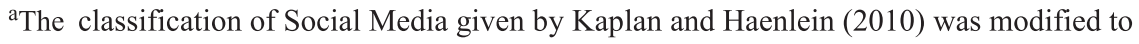
suit the present research needs

\section{Corresponding author}

Snigdha Singh can be contacted at: ssingh7@|ko.amity.edu

For instructions on how to order reprints of this article, please visit our website:

www.emeraldgrouppublishing.com/licensing/reprints.htm

Or contact us for further details: permissions@emeraldinsight.com 